\title{
THE DYNAMICS OF ENTREPRENEURIAL MOTIVATION AMONG WOMEN: A COMPARATIVE STUDY OF BUSINESSWOMEN IN SAUDI ARABIA AND BAHRAIN
}

\author{
Muhammad A. Sadi ${ }^{1 *}$ and Basheer M. Al-Ghazali ${ }^{2}$ \\ ${ }^{I}$ King Fahd University of Petroleum \& Minerals, Dhahran, Saudi Arabia \\ ${ }^{2}$ Naizak Global Engineering Systems, Khobar, Saudi Arabia \\ ${ }^{*}$ Corresponding author: amasadi@kfupm.edu.sa
}

\begin{abstract}
This study explores the underlying dynamics of motivation for women entrepreneurs in Saudi Arabia and Bahrain, using t-test and ANOVA analyses. Various distinct motivational factors were found in both countries. Self-achievement was the most prominent factor motivating Saudi women to start their own businesses. However, for Bahraini women, the profit motive was the most prominent motivational factor.
\end{abstract}

Keywords: businesswomen, entrepreneurship, motivation

\section{INTRODUCTION}

The global outlook for female entrepreneurs has never been more encouraging (Riebe, 2003). Globally, 1 in 10 women is self-employed, and it is estimated that women own and manage up to one-third of all businesses in developed countries. Nelton (1998) regarded this growth of female entrepreneurship since the 1970s, from $5 \%$ to $38 \%$ in 30 years (Hisrich, Brush, Good, \& De Souza, 1997), as one of the most significant, yet quietest, revolutions of our time.

It is evident that the activity of female entrepreneurs is making a distinct difference in their communities and economies, in both developed and developing countries. However, despite the growing number of female entrepreneurs, Starr and Yudkin (1996) state that little is known about women entrepreneurs' business practices, their survival and growth strategies, and their perceptions of their entrepreneurial careers. This is also the case in Saudi Arabia, Bahrain and most Middle Eastern countries. There are limited published studies that explore business start-up motivations among women.

Despite the extent of female entrepreneurs' involvement in new business formation, the economic impact of women-led businesses has been downplayed 
(Carter, Brush, Gatewood, Greene, \& Hart, 2002). Henry (2002) states that female entrepreneurship is an under-researched area with tremendous economic potential and requires special attention.

Although the number of Saudi businesswomen is not that high as compared to businessmen, women have approximately SR 90 billion in untapped resources in bank accounts (Sidiya \& Al-Jassem, 2010).

This study focuses on the reasons why Saudi and Bahraini women choose to start their own businesses. A questionnaire was adopted from a survey on women entrepreneurs in the project "Women in Business and in Decision-Making" in Europe (2004). The main aim of this European survey was to identify the problems that prevent women entrepreneurs from participating in economic decision-making processes in the European countries (www.eurochambres.be).

This paper begins with a review of the literature from both empirical and theoretical perspectives. Then, three research hypotheses are formulated and tested on a sample of Saudi and Bahraini businesswomen and businessmen. The methodology and results of this study are broken down into two parts: Saudi businesswomen and Bahraini businesswomen, followed by limitations and recommendations.

\section{LITERATURE REVIEW}

\section{Women in Business}

Many women worldwide are entrepreneurs. However, the global impact of female entrepreneurs is only now beginning to gain intensity. The number of female business owners continues to increase steadily worldwide, and women in advanced market economies own more than $25 \%$ of all businesses [National Foundation of Women Business Owners (NFWBO), 1998]. Women-owned businesses in Africa, Asia, Eastern Europe, and Latin America are also growing rapidly [Organisation for Economic Co-Operation and Development (OECD), 1998]. For example, women produce more than $80 \%$ of the food for sub-Saharan Africa, $50 \%-60 \%$ for Asia, $26 \%$ for the Caribbean, $34 \%$ for North Africa and the Middle East, and more than 30\% for Latin America. In the U.S., one out of every four company workers is employed by a woman-owned firm, and in the U.S. and Canada, the growth of women-owned firms outpaces overall business growth by approximately 2:1 (Kitching \& Jackson, 2002). Similar findings are reported from Australia and parts of Asia, with more women establishing new small businesses than men and with lower failure rates. In some regions of the world, the transformation to a market economy threatens to increase gender inequality. 
Some of these changes are simply the legacy of a gender imbalance that existed prior to political and economic reforms, whereas other changes reflect a return to traditional norms and values that relegated women to a secondary position. As countries become more democratic, gender inequalities lessen, creating a more productive atmosphere for both sexes.

In a study of nurses who started their own businesses, Roggenkamp and White (1998) found that the desire for greater flexibility was a strong motivator to leave a traditional nursing setting and undertake an entrepreneurial venture. The researchers found that the factors in women's decisions to start their own businesses included aligning with their values, regaining excitement, leadership, self-advancement, and fulfilling lifelong goals.

Dhaliwal and Kangis (2006) found that some women's businesses were hobby related. These findings support Dhaliwal's (1998) suggestion that many women choose roles as entrepreneurs as an extension of the roles associated with being Asian women or wives. Most of the women had family members in business and relied on private and family funds to develop their businesses.

\section{Motivations for Start-ups}

Entrepreneurs' personal motivations for initiating start-up activities have received significant attention in the entrepreneurial literature (Carter, 2000a; 2000b) and are among the key components for entrepreneurial success (Timmons \& Spinelli, 2003). The literature reveals various "push" and "pull" factors as motivators for business start-ups (Alstete, 2003) or, alternatively, negative and positive factors, as discussed by Deakins and Whittam (2000). The "push" (or negative) factors are associated with the necessities that force a woman into pursuing her business plan. These factors can include redundancy, unemployment, frustration with previous employment, the need to earn a reasonable living and the need for a flexible work schedule, reflecting the family caretaking role that is still expected from women (Alstete, 2003; Orhan \& Scott, 2001). Similarly, Carter and Cannon (1988) found evidence of a "glass ceiling effect" that impedes executive women from reaching senior executive positions and thus pushes them from management positions into their own businesses. In fact, Catley and Hamilton (1998) state that self-employment was a last resort for some women involved in their study. Similarly, Deakins and Whittam (2000) emphasise that although becoming an entrepreneur is not a first choice in this situation, negative motivational factors are more important among entrepreneurs from certain social groups that may face discrimination, such as ethnic minority groups, younger age groups and women.

The "pull" (or positive) factors are those associated with factors of choice (Orhan \& Scott, 2001) and entrepreneurial aspirations (Deakins \& Whittam, 2000). 
These factors relate to independence, self-fulfilment, autonomy, selfachievement, being one's own boss, using creative skills, doing enjoyable work, the entrepreneurial drive and the desire for wealth, social status and power (Alstete, 2003; Orhan \& Scott, 2001). The need for independence and the challenge of business ownership are the most frequently cited 'pull' motivators for women entrepreneurs (Carter \& Cannon, 1992). Furthermore, it has been suggested that women are motivated by the social contributions their business can make (Orhan \& Scott, 2001). According to Still and Timms (2000a, 2000b), women start businesses with the objective of "making a difference." Women are more client-focused than men, tend to operate ethically and make a social contribution in addition to pursuing economic motives. Rosa, Carter, and Hamilton (1996) add that women do not enter business for financial gain but to pursue intrinsic goals, such as independence and the flexibility to interface family and work commitments.

Exploratory research by Mcelwee and Riyami (2003) examined the motivation for women's entrepreneurship in Oman and the barriers to women's success. The most prominent factors that motivated women entrepreneurs were enjoyment, finance and job satisfaction. The study revealed that women tend to define success differently from men, and women's motivation differs from the motivations of men. Women appear to be satisfied by micro-level entrepreneurial activities, aiming for stability rather than growth, and they generally have less access to external funding than men. Thus, women's businesses tend to be concentrated in service sectors that usually require a small initial capital outlay and less technical knowledge.

A recent study by Naser, Mohammed and Nuseibeh (2009) identified factors that motivate women in the United Arab Emirates to become business entrepreneurs. This study indicated that financial support from the government (especially in the start-up phase), self-fulfillment, knowledge, skill, experience and spousal relationships were important factors in the development of women's entrepreneurship.

\section{Women in Business in Saudi Arabia}

Data on the economic status of women in Saudi Arabia are inconsistent, but they suggest substantial economic involvement in the country. According to a study at King Abdulaziz University in Jeddah, Saudi women hold nearly $70 \%$ of the bank accounts in the Kingdom, with deposits worth SAR 62 billion. They hold $20 \%$ of corporate shares and own $15 \%$ of the private companies and $10 \%$ of the real estate sector (Abdul Ghafour, 2004). There are approximately 23,000 Saudi businesswomen (Alshemari, 2005). 
Other studies report that Saudi women own $40 \%$ of the private wealth and approximately 15,000 commercial establishments, or $10 \%$ of private businesses, in Saudi Arabia (Doumato, 2003). The Saudi Arabian General Investment Authority (SAGIA) decided to offer its services to Saudi businesswomen and to establish a "one-stop" service centre for women only, staffed by professional female experts who could ensure privacy while providing fully services to both Saudi and foreign businesswomen intending to invest in the Kingdom. SAGIA was encouraged by the response of Saudi women, a large number of whom have applied for investment licenses (Ramady, 2005).

Recently, a landmark study conducted by Alturki and Braswell (2010) provided interesting information on Saudi women in business. According to this study, $87 \%$ of businesswomen in Saudi Arabia owned their businesses, and 78\% owned their businesses completely. Of these business owners, 52\% were sole owners, $42 \%$ had an additional male owner and $33 \%$ co-owned with a female relative. According to this study, few businesswomen are engaged in international business. Approximately $21.3 \%$ of registered businesswomen and $12.9 \%$ of unregistered businesswomen import goods and services, and $4.5 \%$ of registered and $1.6 \%$ of unregistered businesswomen are involved in both importing and exporting (Alturki \& Braswell, 2010).

\section{Women in Business in Bahrain}

Having benefited from the significant opportunities for higher education provided by the government, Bahraini women account for a significant part of the country's graduates. In 2001, Ms. Mona Al-Moayed was the first woman elected to the Bahrain Chamber of Commerce and Industry (BCCI). By 2003, the number of women members had reached 1,785, representing $15 \%$ of the BCCI's membership. Seikaly (1994) found that women were convinced that the general employment policy of the government sector in Bahrain blocks the promotion of women, even when they are better qualified, more thoroughly trained and have more experience than men. Wilkinson's (1996) study of UAE, Omani and Bahraini women in top management positions found that the challenges faced by these women included overt discrimination at work, cultural taboos, negative attitudes towards working women and a lack of confidence and trust in women managers.

Empirical evidence on Bahrain and Oman reported by Dechant and Al-Lamky (2005) found that pull factors, such as opportunity, the need for achievement, self-fulfillment and the desire to help others, motivated women to become entrepreneurs in most cases. Additionally, they confirmed that women tend to invest mainly in the services sector. The average size of Bahraini businesses run 
by women is small, and the number of personnel employed ranges between 2 and 60 .

\section{RESEARCH OBJECTIVES AND HYPOTHESIS}

This study focuses on the reasons (motives) why Saudi and Bahraini women choose to start their own businesses. Motivations based on the opinions of both businesswomen and businessmen are presented. Then, the following hypotheses are tested:

H1: There is a significant difference between the views of businesswomen and businessmen regarding the main motivational factor.

$\mathrm{H} 2$ : There are significant differences in motivational factors among businesswomen across Saudi Arabia and Bahrain.

H3: There is a significant impact of age when starting a business on the motivational factors for women.

\section{METHODOLOGY}

The questionnaire was modified from a survey on women entrepreneurs in the European project "Women in Business and in Decision-Making" (2004), as mentioned in the first part of the paper. The survey used a five-point Likert scale to record the respondent's agreement or disagreement with the statements. Each survey was followed by demographical questions to assist with the analysis. The participants included 330 women entrepreneurs, out of a total of 700 contacted (a response rate of 47\%). The questionnaire was translated into the Arabic language and verified using back translation, parallel translation and decentring techniques to identify errors in back translation (the questionnaire was translated from English language to Arabic language, and then a second party translated it back into the original). This process helped to identify misinterpretations and misunderstandings before they reached the public. Because back translation may not be accurate due to idioms in both languages, parallel and decentering translation techniques were also used. In this process, more than two translators (different each time) were used for the back translation. The results were compared, the differences were discussed, and the most appropriate translation was selected for a pilot test. The pilot test validated the translation techniques adopted (Cateora, Gilly \& Graham, 2009). The sample consisted of Saudi-owned SMEs and Bahraini-owned SMEs. Samples of 330 in Saudi Arabia and 80 in 
Bahrain were considered adequate to measure the characteristics of the population. Because neither kingdom has a research culture, the sample sizes were justified for further processing. Because the sample size was also in line with the convenience sampling procedure described by Zikmund (2004) and Kumar, Aakar and Day (2009). These authors agree that the sample size depends on the number of people willing and available for questioning, and the size should be convenient, economical and relatively easy to approach. No specific sample size range is recommended by the writers to make inferences about the population.

\section{Sample and Data Collection in Saudi Arabia}

Two methods were followed to collect the data:

1. Administering an online survey: the received responses were sent directly to the web server of King Fahd University of Petroleum \& Minerals. An e-mail was sent to approximately 300 businesswomen and businessmen requesting their participation in the survey. The mailing list was provided by a Saudi businesswoman at the Dammam Chamber of Commerce.

2. Drop-off and pick-up method: two sets of the questionnaire were delivered to both the businesswomen's centre and the businessmen's centre in the Chamber of Commerce in the Eastern Province, requesting the participation of 200 businesswomen and 200 businessmen. All valid responses that were used for further processing are shown in Table 1.

Table 1

Data collection in Saudi Arabia

\begin{tabular}{lccc}
\hline & Businesswomen & Businessmen & Total \\
\hline Drop-off and pick-up method & 52 & 56 & 108 \\
Online survey method & 113 & 109 & 222 \\
\hline Total & $\mathbf{1 6 5}$ & $\mathbf{1 6 5}$ & $\mathbf{3 3 0}$ \\
\hline
\end{tabular}

The sample size was appreciably smaller before reaching the 165-165 sample size balance between businesswomen and businessmen. To achieve the 165-165 balance, another round of data collection was conducted using the two abovementioned data collection methods.

\section{Reliability and normality tests}

After the data were uploaded with SPSS software, the reliability of the data was tested and found to have a Cronbach's alpha of 0.879. This test indicated that if 
the survey was conducted 100 times in Saudi Arabia, the researchers would receive the same results $88 \%$ of the time.

\section{Sample and Data Collection in Bahrain}

The data were collected with the help of the Bahrain Women's Society. The total number of women-owned businesses that agreed to participate was 80 out of 170 (a response rate of $47 \%$ ). A total of two rounds were attempted. Before reaching the 40-40 sample size balance between businesswomen and businessmen, the sample size in the first round was 35 women and 30 men. To achieve the $40-40$ sample size balance, a second round of data collection was conducted using the above two data collection methods. Table 2 shows the two collection methods.

Table 2

Data collection in Bahrain

\begin{tabular}{lccc}
\hline & Businesswomen & Businessmen & Total \\
\hline Drop-off and pick-up method & 10 & 12 & 22 \\
Online survey method & 30 & 28 & 58 \\
\hline Total & $\mathbf{4 0}$ & $\mathbf{4 0}$ & $\mathbf{8 0}$ \\
\hline
\end{tabular}

\section{Reliabiity and normality tests}

After the data were uploaded in SPSS software, the reliability of the data was tested and found to be 0.858 .

\section{Analysis and Results in Saudi Arabia and in Bahrain}

\section{Techniques}

The descriptive statistics, $t$-test and ANOVA were used for the analysis. Descriptive statistics (mean computation and comparison) were used to determine the start-up motivation among women entrepreneurs in Saudi Arabia and Bahrain.

The $t$-test was used to measure the significance of the difference in means for the main motivation factor for Saudi and Bahraini businesswomen according to businesswomen and businessmen. The ANOVA test was used to examine the significant difference of some demographical data in the motivation factors for businesswomen. 


\section{Descriptive statistics}

Table 3 summarises the output of the descriptive statistics, in which the means were compared to determine the business start-up motivation and the main barriers facing women entrepreneurs in Saudi Arabia and Bahrain.

In Saudi Arabia, both businessmen and businesswomen agreed that selfachievement was the most important motivating factor for Saudi women's business start-ups. In Bahrain, the main motivating factor was the profit motive, according to businesswomen.

Table 3

Comparative results of the descriptive statistics ( $m=$ mean value)

\begin{tabular}{|c|c|}
\hline Bahrain & Saudi Arabia \\
\hline $\begin{array}{l}\text { The main motivation factors for business start- } \\
\text { ups from Bahraini businesswomen's point of } \\
\text { view are (1) profit motive }(m=1.40) ;(2) \\
\text { working independently }(m=1.60) ;(3) \text { control } \\
\text { and freedom for decision making }(m=1.65) \text {; } \\
\text { and (4) social status }(m=1.70) \text {. }\end{array}$ & $\begin{array}{l}\text { The main motivation factors for business start- } \\
\text { ups from Saudi businesswomen's point of view } \\
\text { are (1) self-achievement }(m=1.36) \text {; ( } 2) \\
\text { working independently }(m=1.61) \text {; (3) self- } \\
\text { confidence }(m=1.62) \text {; and (4) profit motive } \\
(m=1.69) \text {. }\end{array}$ \\
\hline $\begin{array}{l}\text { The main motivation factors for business start- } \\
\text { ups from Bahraini businessmen's point of view } \\
\text { are (1) self-confidence }(m=1.58) ;(2) \text { self- } \\
\text { achievement }(m=1.80) ;(3) \text { profit motive } \\
(m=1.83) \text {; and }(4) \text { control and freedom for } \\
\text { decision making }(m=1.90) \text {. }\end{array}$ & $\begin{array}{l}\text { The main motivation factors for business start- } \\
\text { ups from Saudi businessmen's point of view are } \\
\text { (1) self-achievement }(m=1.85) \text {; ( } 2) \text { profit } \\
\text { motive }(m=1.85) \text {; (3) lack of jobs in public } \\
\text { sector }(m=1.93) \text {; and (4) self-confidence } \\
(m=1.94) \text {. }\end{array}$ \\
\hline
\end{tabular}

\section{Independent samples test}

The $t$-test was used to measure the significance of the difference in means for the main motivation factor for Saudi and Bahraini businesswomen according to businesswomen and businessmen.

In Saudi Arabia, the profit motive and control and freedom for decision making had no statistically significant differences between the means for businessmen and businesswomen $(p>0.05)$, as shown in Table 4 . The self-achievement, working independently, social status and self-confidence motives are shown a statistically significant difference when the means of businessmen and businesswomen were compared $(p<0.05)$. Therefore, the null hypothesis is accepted, and the following hypothesis is rejected. 
H1: There is a significant difference between the views of businesswomen and businessmen regarding the main motivation factor, which is self-achievement $(t=5.718, p=0.000<0.05)$ in Saudi Arabia and profit $(t=2.342, p=0.022<0.05)$ in Bahrain. Therefore, this test reveals that self-achievement is a significant factor that motivates businesswomen in Saudi Arabia, but not in Bahrain $(p=0.294>0.05)$, as shown in Table 4. However, the profit motive is a significant factor that motivates businesswomen in Bahrain, but not in Saudi Arabia $(p=0.074>$ $0.05)$.

$\mathrm{H} 2$ : $\quad$ There is a significant difference in motivation factors among businesswomen across Saudi Arabia and Bahrain. The null hypothesis is rejected, and the hypothesis is accepted. The difference in motivational factors is significant among businessmen and businesswomen across Saudi Arabia and Bahrain.

Table 4

Independent samples test (t-test for equality of means)

\begin{tabular}{|c|c|c|c|c|c|c|c|}
\hline & & \multicolumn{3}{|c|}{ Saudi Arabia } & \multicolumn{3}{|c|}{ Bahrain } \\
\hline & & $t$ & $\begin{array}{l}\text { Sig. (2- } \\
\text { tailed) }\end{array}$ & $\begin{array}{l}\text { Mean } \\
\text { diff. }\end{array}$ & $t$ & $\begin{array}{l}\text { Sig. (2- } \\
\text { tailed) }\end{array}$ & $\begin{array}{l}\text { Mean } \\
\text { diff. }\end{array}$ \\
\hline \multirow{2}{*}{$\begin{array}{l}\text { She has a profit } \\
\text { motive. }\end{array}$} & $\begin{array}{l}\text { Equal variances } \\
\text { assumed }\end{array}$ & 1.792 & .074 & .164 & 2.342 & .022 & .425 \\
\hline & $\begin{array}{l}\text { Equal variances not } \\
\text { assumed }\end{array}$ & 1.792 & .074 & .164 & 2.342 & .023 & .425 \\
\hline \multirow{2}{*}{$\begin{array}{l}\text { She likes to } \\
\text { work } \\
\text { independently. }\end{array}$} & $\begin{array}{l}\text { Equal variances } \\
\text { assumed }\end{array}$ & 4.781 & .000 & .442 & .000 & 1.000 & .000 \\
\hline & $\begin{array}{l}\text { Equal variances not } \\
\text { assumed }\end{array}$ & 4.781 & .000 & .442 & .000 & 1.000 & .000 \\
\hline \multirow{2}{*}{$\begin{array}{l}\text { She wants } \\
\text { control and } \\
\text { freedom for } \\
\text { decision } \\
\text { making. }\end{array}$} & $\begin{array}{l}\text { Equal variances } \\
\text { assumed }\end{array}$ & .981 & .327 & .115 & 1.233 & .221 & .225 \\
\hline & $\begin{array}{l}\text { Equal variances not } \\
\text { assumed }\end{array}$ & .981 & .327 & .115 & 1.233 & .221 & .225 \\
\hline \multirow{2}{*}{$\begin{array}{l}\text { She looks for } \\
\text { social status. }\end{array}$} & $\begin{array}{l}\text { Equal variances } \\
\text { assumed }\end{array}$ & 3.236 & .001 & .327 & .226 & .822 & .050 \\
\hline & $\begin{array}{l}\text { Equal variances not } \\
\text { assumed }\end{array}$ & 3.236 & .001 & .327 & .226 & .822 & .050 \\
\hline
\end{tabular}

(continued on next page) 
Table 4 (continued)

\begin{tabular}{llccccccc}
\hline & & \multicolumn{5}{c}{ Saudi Arabia } & \multicolumn{5}{c}{ Bahrain } \\
\cline { 2 - 8 } & $t$ & $\begin{array}{l}\text { Sig. (2- } \\
\text { tailed) }\end{array}$ & $\begin{array}{l}\text { Mean } \\
\text { diff. }\end{array}$ & $t$ & $\begin{array}{l}\text { Sig. (2- } \\
\text { tailed) }\end{array}$ & $\begin{array}{l}\text { Mean } \\
\text { diff. }\end{array}$ \\
\hline $\begin{array}{l}\text { She looks for } \\
\text { self- } \\
\text { achievement. }\end{array}$ & $\begin{array}{l}\text { Equal variances } \\
\text { assumed }\end{array}$ & 5.718 & .000 & .497 & 1.056 & .294 & .200 \\
\cline { 2 - 8 } & $\begin{array}{l}\text { Equal variances not } \\
\text { assumed }\end{array}$ & 5.718 & .000 & .497 & 1.056 & .294 & .200 \\
\hline \multirow{3}{*}{$\begin{array}{l}\text { She has self - } \\
\text { confidence. }\end{array}$} & $\begin{array}{l}\text { Equal variances } \\
\text { assumed }\end{array}$ & 3.423 & .001 & .321 & .551 & .583 & .075 \\
\cline { 2 - 8 } & $\begin{array}{l}\text { Equal variances not } \\
\text { assumed }\end{array}$ & 3.423 & .001 & .321 & .551 & .583 & .075 \\
\hline
\end{tabular}

\section{Analysis of variance (ANOVA)}

To examine the significant difference in the demographic data on the age when starting a business for motivation factors for women, a one-way ANOVA test was applied.

From the SPSS output for the ANOVA test in Table 5, it is clear that the $p$ for Saudi Arabia are greater than 0.05 . Therefore, the null hypothesis is accepted, and the following hypothesis is rejected.

H3: There is a significant impact of age when starting a business on the motivation factors for Saudi women. Therefore, this test reveals that the age for starting a business is 20-30 years old. However, there is no significant impact of women's age when starting a business on the motivation factors for Bahraini women because some $p$ are less than 0.05 , as shown in Table 5 . 


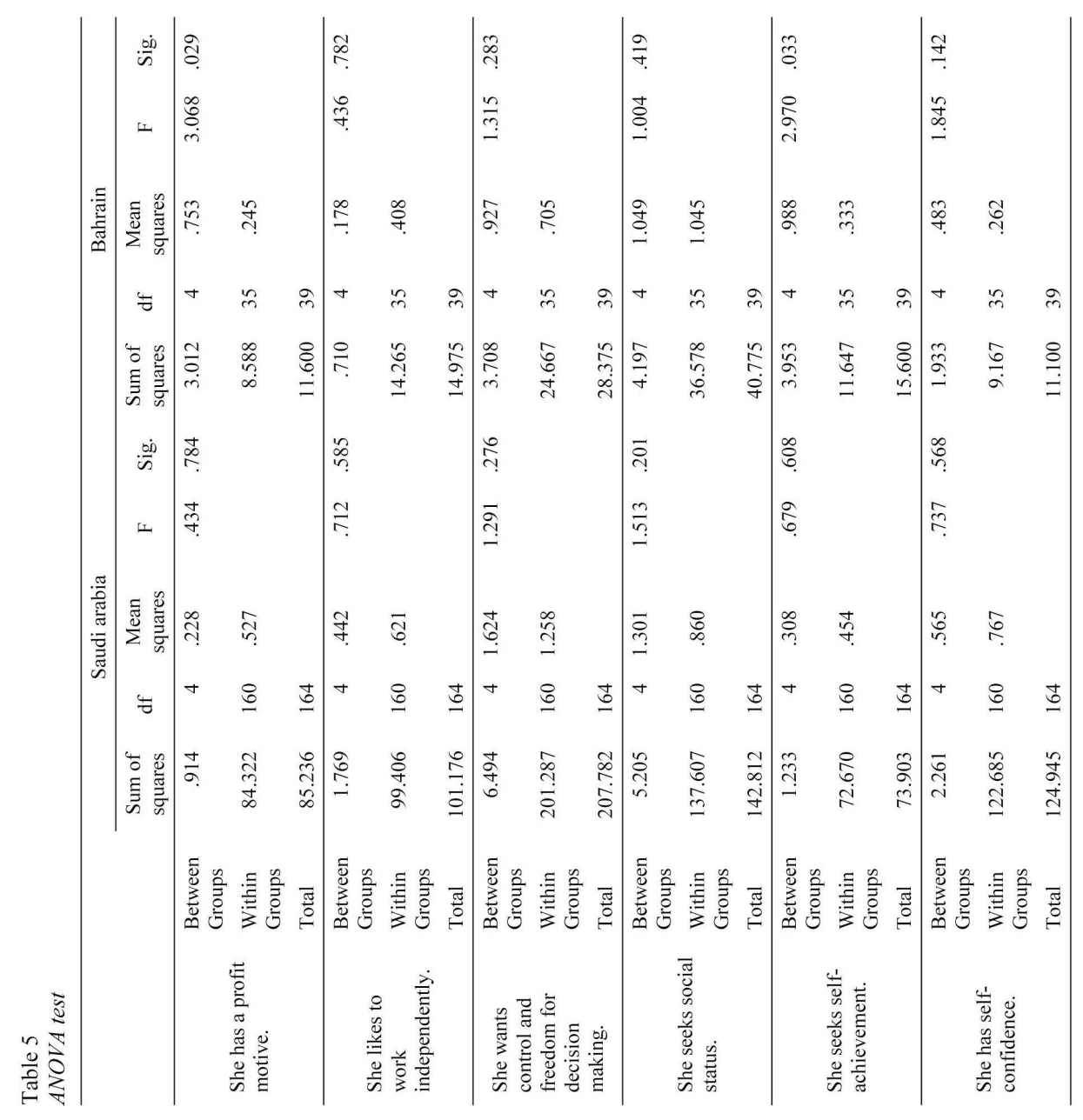




\section{Implications for Academia, Regulatory Bodies and Industry}

\section{The case of Saudi businesswomen}

The study helps to identify the factors that motivate Saudi businesswomen to start and operate businesses of their own. This research can be useful for examining issues related to women's participation in entrepreneurship. Governmental bodies, chambers of commerce and industries may find these results helpful when developing appropriate rules, regulations, and strategies in connection with women's participation in business. As noted in the literature search, women's participation as entrepreneurs is crucial for improving the economy and the social life of any country.

The results of this study reveal a need to understand the main motivational factors for Saudi businesswomen's success in the business world.

This study contributes to enhancing the responsibility of business entrepreneurs in creating new jobs through Small and Medium-sized Enterprises (SMEs). Businesswomen have a responsibility to upgrade not only their own skills in business management but also the skills of their respective workforce.

Many businesswomen refused to complete the questionnaire simply because they were not registered with the government. They were reluctant to involve a mandatory third party, known as a muaqqib or a male manager, to handle their affairs and to intercede on their behalf. However, most businesswomen were able to utilise their relative services to resolve this issue internally. A number of ambiguous regulations seem to exist for the licensing of business activities. Some of these activities relate to varied regulatory bodies, increasing the difficulty for businesswomen to liaison with various governmental departments. It is also important to note that Saudi businesswomen face a lack of informational support. Most Saudi women dislike the lengthy amount of time needed to process their registration with governmental departments. As a result, they remain unregistered and unlicensed, resulting in missed opportunities in the business world.

\section{The case of businesswomen in Bahrain}

The profit motive and self-achievement are the most important factors motivating Bahraini women's business start-ups. 


\section{LIMITATIONS OF THE STUDY}

Both kingdoms lack a comprehensive research culture, rendering any efforts to study business issues concerning women entrepreneurs extremely difficult. It is next to impossible to contact Saudi businesswomen, even through the offices of the Chambers of Commerce. The Bahraini Women's Society is somewhat liberal, but is not particularly responsive. The researchers were able to contact businesswomen only through the most arduous of efforts, by creating contacts through the business centres at the Chambers of Commerce and the Bahraini Women's Society and through e-mail.

Some businesswomen were unfortunately unaware of the importance of research work and were reluctant to cooperate when asked to participate in the questionnaire. Most businesswomen were also sensitive about revealing their email contact information. Consequently, many preferred not to respond via e-mail.

Despite the fact that Cronbach's alpha provided sufficient results to lend the needed validity to our research, the sample cannot be considered a total and complete representation of the subject matter. The study utilised a sample population from the Eastern Province and Manama. The sample population utilised for the Riyadh province and the Western Province was limited.

\section{RECOMMENDATIONS}

The following are recommendations for the industry sectors, government ministries and chambers of commerce to support and facilitate women's entrepreneurship.

1. Empower women-only sections of major governmental ministries. Devise implementation strategies for women's transition into international trade.

2. Appoint women as members of the Shoura Council so that the interests of businesswomen are protected.

3. Allow businesswomen to travel freely without legal, social, or traditional restrictions.

4. Improve governmental and societal encouragement of women's participation in economic issues, nation building, innovation, and productivity.

5. Ensure self-achievement for businesswomen by not requiring muaqqub male managers to serve as intercessors for women's business interests. Ultimately, businesswomen are advised to enable themselves to think judiciously and plan prospectively. They should implement strategies 
efficiently and effectively as well as being objective evaluators. It is best to advance diplomatically, and women should not be discouraged by the prospect of failure. Multiple attempts that fail can eventually lead to success.

\section{CONCLUSION}

This study revealed that self-achievement was the most important motivating factor for Saudi businesswomen starting businesses. Saudi businesswomen are integral to the growth and expansion of entrepreneurship in the Kingdom. Government regulations must be revised to encourage greater involvement of women in businesses and in the work place. Although SMEs run by businesswomen do not require sophisticated technology or stylish marketing tools, the lack of this technology may deter their business efficiency.

The profit motive and self-achievement are the most important factors that motivate Bahraini women to start businesses.

Few research studies of this type have been undertaken in the Middle East. In the United Arab Emirates, Naser, Mohammed and Nuseibeh conducted a study in 2009 to determine the factors that affect women entrepreneurs. Their findings are mentioned in the literature review section. However, this study is based on different premises and presents somewhat different viewpoints.

\section{REFERENCES}

Abdul Ghafour, P. K. (2004). Women to take up Business Issues. Arab News, 4 June.

Alstete, J. W. (2003). On becoming an entrepreneur: An evolving typology. International Journal of Entrepreneurial Behavior \& Research, 4, 222-234.

Alturki, N., \& Braswell, R. (2010). Businesswomen in Saudi Arabia: Characteristics, challenges, and aspirations in a regional context. Saudi Arabia: Monitor Group.

Carter, N., Brush, C., Gatewood, E., Greene, P., \& Hart, M. (2002). Does enhancing women's financial sophistication promote entrepreneurial success? Paper presented at Promoting Female Entrepreneurship: Implications for Education, Training and Policy Conference, Dundalk Institute of Technology, Dundalk, 19 November.

Carter, S. (2000a). Improving the numbers and performance of women-owned businesses: Some implications for training and advisory services. Education + Training, $42(4 / 5), 326-334$.

Carter, S. (2000b). Gender and enterprise. In S. Carter, \& D. Jones-Evans (Eds.), Enterprise and small business: Principles, practice and policy (pp. 168-181). London: Financial Times Prentice-Hall.

Carter, S., \& Cannon, T. (1992). Women as entrepreneurs. London: Academic Press. 
Cateora, R. P., Gilly, C. M., \& Graham, J. I. (2009). International marketing. Boston: McGraw Hill/Irwin.

Catley, S., \& Hamilton, R. (1998). Small business development and gender of owner. Journal of Management Development, 17(1), 75-82.

Deakins, D., \& Whittam, G. (2000). Business start-up: Theory, practice and policy. In S. Carter, \& D. Jones-Evans (Eds.), Enterprise and small business: Principles, practice and policy (pp. 115-131). London: Financial Times Prentice-Hall.

Dechant, K., \& Al-Lamky, A. (2005). Towards an understanding of Arab women entrepreneurs in Bahrain and Oman. Journal of Developmental Entrepreneurship, 10(2), 123-40.

Dhaliwal, S. (1998). Silent contributors - Asian female entrepreneurs and women in business. Women's Studies International Forum, 21(5), 463-474.

Dhaliwal, S., \& Kangis, P. (2006). Asians in the UK: Gender, generations and enterprise. Equal Opportunities International, 25(2), 92-108.

Doumato, E. A. (2003). Education in Saudi Arabia: Gender, jobs and the price of religion. In E. Doumato, \& M. Poususney (Eds.), Women and globalization in the Arab Middle East - Gender, economy and society (pp. 239-258). New York: Lynne Reinmer Inc.

Fielden, S. L., Davidson, M. J., Dawe, A. J., \& Makin, P. J. (2003). Factors inhibiting the economic growth of female-owned small businesses in North West England. Journal of Small Business \& Enterprise Development, 10(2), 152-166.

Henry, C. (2002). Closing remarks, at research forum: Promoting Female Entrepreneurship - Implications for Education, Training and Policy. Centre for Entrepreneurship Research, Dundalk Institute of Technology, Dundalk, 19 November.

Hisrich, R., Brush, C., Good, D., \& De Souza, G. (1997). Performance in entrepreneurial ventures: Does gender matter? Frontiers of Entrepreneurship Research: Conference Proceedings, Babson College, Babson Park, MA.

Kitching, B. M., \& Jackson, P. A. (2002). Businesswomen in China. The International Journal of Entrepreneurship and Innovation, 3(2), 145-155.

Kumar, V., Aaker, D., \& Day, G. (2009). Essentials of marketing research. New Jersey: Wiley.

McElwee, G., \& Al-Riyami, R. (2003). Women entrepreneurs in Oman; some barriers to success. Career Development International, 8(7), 339-346.

Naser, K., Mohammed, W. R., \& Nuseibeh, R. (2009). Factors that affect women entrepreneurs: Evidence from emerging economy. International Journal of Organizational Analysis, 17(3), 247.

National Foundation of Women Business Owners (NFWBO) (1998). Women entrepreneurs are a growing trend. Washington, DC: National Foundation of Women Business Owners.

Nelton, S. (1998). Women's firms thrive. Nation's Business, August.

Organisation for economic Co-operation and Development, (OECD). (1998). Women entrepreneurs in small and medium enterprises, OECD Proceedings. Paris: OECD.

Orhan, M., \& Scott, D. (2001). Why women enter into entrepreneurship: An explorative model. Women in Management Review, 16(5), 232-247. 
Ramady, M. (2005). The Saudi Arabian economy. New York: Springer Science Business Media, Inc.

Riebe, M. (2003). Growth-orientated women entrepreneurs: Making it their way, International Council for Small Business Proceedings; Advancing Entrepreneurship and Small Business, 48th World Conference, Belfast, 15-18 June.

Roggenkamp, S. D., \& White, K. R. (1998). Four nurse entrepreneurs: What motivates them to start their own business. Health Care Management Review, 23(3), 67-75.

Rosa, P., Carter, S., \& Hamilton, D. (1996). Gender as a determinant of small business performance: Insights from a British study. Small Business Economics, 8, 463 78.

Seikaly, M. (1994). Women and social change in Bahrain. International Journal of Middle East Studies, 26, 415-426.

Sidiya, F., \& Al-Jassem, D. (2010). Forum discusses strategy to empower women. Arab News, 9 December.

Starr, J., \& Yudkin, M. (1996). Women entrepreneurs: A review of current research. Wellesley, MA: Wellesley College Centre for Research on Women.

Still, L.V., \& Timms, W. (2000a). Making a difference: The values, motivations and satisfaction, measures of success, operating principles and contributions of women small business owners. Discussion paper series. Perth, Australia: Centre for Women and Business, The University of Western Australia.

Still, L.V., \& Timms, W. (2000b). Women's business: The flexible alternative work style for women. Women in Management Review, 15(5/6), 272-283.

Timmons, J. A., \& Spinelli, S. (2003). New venture creation: Entrepreneurship for the 21st century. Singapore: McGraw-Hill.

Wilkinson, G. (1996). Women in business. Gulf Business, 109, Dubai.

Zikmund, W. G. (2004). Exploring marketing research. New York: The Dryden Press. 